\title{
Non-specific and peculiar psychological mechanisms in criminological process of perpetrators of manslaughters
}

\section{Niespecyficzne i specyficzne mechanizmy psychologiczne w procesie kryminogenezy sprawców zabójstw}

\author{
Andrzej Borowski \\ Department of Sociology and Social Works, Faculty of Education and Philosophy, \\ Pomeranian University in Słupsk, 64 Westerplatte St., 76-200 Słupsk, Poland \\ E-mail address: aubor@poczta.onet.pl
}

\begin{abstract}
Examining psychological mechanisms which lay at the heart of manslaughters aren't a new subject in Polish psychology and penitentiary sociology. In case of the public correction he seems positive to be influence relatively of short stay in penitentiary individuals. In case of the psychological correction long-term therapy is giving greater effects. Undervalued through penitentiary administration of the factor criminological process there is an influence of media, and by force methods of proceedings are marked most popular /with innovative/ middle of achieving desired objectives socially.
\end{abstract}

Keywords: murderer; peculiar and non-specific mechanisms; criminological process; media

\section{STRESZCZENIE}

Badanie mechanizmów psychologicznych jakie legły u podstaw zabójstw nie są tematem nowym w polskiej psychologii i socjologii penitencjarnej. W przypadku korekcji społecznej pozytywny wydaje się być wpływ stosunkowo krótkiego pobytu w jednostkach penitencjarnych. W przypadku korekcji psychicznej większe efekty daje długotrwała terapia. Niedocenianym przez administrację penitencjarną czynnikiem kryminogenezy jest wpływ środków masowego przekazu,a nacechowane przemocą metody postępowania są najpopularniejszym /innowacyjnym/ środkiem osiągania społecznie pożądanych celów.

Stowa kluczowe: zabójca, mechanizmy specyficzne i niespecyficzne, kryminogeneza, media. 


\section{WPROWADZENIE}

Badanie mechanizmów psychologicznych jakie legły u podstaw zabójstw nie są tematem nowym w polskiej psychologii i socjologii penitencjarnej. Publikowane Pastwa Wojciechowska [1] wyniki badań nad genezą zabójstw pozwalają wyodrębnić pięć kategorii ich sprawców:

- zabójcy „ekonomiczni”, cechujący się słabą internalizacją norm etycznych i niską wrażliwością moralną; opuszczający się zabójstwa z powodów materialnych i chęci zysku,

- sprawcy zabójstw na tle seksualnym traktowanych jako główna przyczyna, bądź jako sposób na zamaskowanie prawdziwego tła zbrodni,

- sprawcy zabójstw z lubieżności /m.in. dotknięci chorobą parafilii - sadyzmu seksualnego/,

- sprawcy chorzy psychicznie dokonujący czynów karalnych z powodu swoich schorzeń /urojenia, halucynacje/,

- kobiety zabójczynie /w znacznej części dzieciobójczynie/.

\section{TEORETYCZNE ROZWAŻANIA NAD CZYNNIKAMI KRYMINOGENEZY ZABÓJSTW}

Jak zauważa Ciosek [2], sprawcy zabójstw charakteryzują się zdecydowanie częściej nie zaburzeniami typu psychotycznego lecz poważnymi zaburzeniami osobowości, określonymi jako defekty psychopatycznie, socjopatyczne lub charakteropatyczne.

Autor ten podkreśla również, że niezależnie od czynnika jakim jest obecnie wpływ opinii publicznej, mediów i deklaracje polityczne podstawową przesłanką postępowania diagnostycznego nawet w przypadkach tzw. morderców seryjnych jest zasada traktowania każdego czynu przestępczego tego rodzaju jako niepowtarzalnego/ mającego swe specyficzne uwarunkowania.

Badania oparto na materiale zgromadzonym w więziennych aktach skazanychsprawców zabójstw. Pierwsza część tych akt zawiera sentencje wyroków zazwyczaj z pisemnym uzasadnieniem - nierzadko z dwóch instancji. Druga część akt /osobopoznawcza/ dostarcza informacji dotyczących stanu psychicznego skazanego bezpośrednio po dokonaniu czynu i aresztowaniu oraz $\mathrm{z}$ reguły wyniki szczegółowych badań psychiatrycznych i psychologicznych.

Badania psychiatryczne zlecane są przez sąd zazwyczaj podczas trwania tymczasowego aresztu przed wydaniem wyroku skazującego przyjmując postać opinii sądowo psychiatrycznej. Badania psychologiczne połączone $\mathrm{z}$ ogólnymi badaniami lekarskimi stanowią ich kontynuację i są $\mathrm{z}$ reguły wykonywane po wydaniu wyroku skazującego przyjmując postać orzeczenia psychologiczno- penitencjarnego.

Badana zbiorowość to mężczyźni odbywający karę bądź tymczasowo aresztowani $\mathrm{w}$ końcowym etapie postępowania przygotowawczego związanego z popełnieniem przez nich przestępstwa $\mathrm{z}$ art. $148 \mathrm{kk}$. /zbrodnia zabójstwa/.

Do przyczyn specyficznych skutkujących popełnieniem przez poszczególnych sprawców przestępstwa zabójstwa zaliczono:

- zmiany w CUN

- wcześniejszą karalność sądową 
- wcześniejszy pobyt w zakładzie wychowawczym, poprawczym lub karnym

- uzależnienie od alkoholu

- zażywanie narkotyków

- udział w podkulturze przestępczej

- wcześniejsze czyny autoagresywne

- ograniczona poczytalność w chwili czynu

Do przyczyn niespecyficznych zaliczono:

- wiek sprawcy

- tendencję do zachowań agresywnych

- pochodzenie z rodziny z problemem alkoholowym

- pochodzenie $\mathrm{z}$ rodziny $\mathrm{z}$ problemem stosowania przemocy

\section{WYNIKI BADAŃ W JEDNOSTCE PENITENCJARNEJ TYPU ZAMKNIĘTEGO}

Badaniami objęto całą populację osadzonych /skazani i tymczasowo aresztowani/ przebywających w jednym z zakładów karnych dla osób odbywających karę po raz pierwszy i młodocianych, którym w wyroku lub postanowieniu o tymczasowym aresztowaniu zarzucono dokonanie przestępstwa $\mathrm{z}$ art. $148 \mathrm{kk}$.

W badanej populacji zdecydowaną większość stanowili skazani - $87 \%$, pozostałe $13 \%$ stanowili tymczasowo aresztowani. Większość osadzonych objętych badaniami miała już sporządzone opinie sądowo psychiatryczne $-80 \%$, pozostałe osoby /zwłaszcza tymczasowo aresztowani/ oczekiwali na ich wykonanie.

W przypadku osadzonych nie posiadających opinii sądowo psychiatrycznej informacje niezbędne do przeprowadzenia badań uzyskiwano z orzeczeń psychologiczno-penitencjarnych /sporządzanych w jednostce penitencjarnej/ oraz z notatek psychologa i wychowawców. Występowanie zmian w Centralnym Układzie Nerwowym /CUN/ skutkujące występowaniem zaburzeń organicznych osobowości /charakteropatią/ stwierdzono u $45 \%$ badanych. Mimo, iż $\mathrm{w}$ żadnym $\mathrm{z}$ badanych przypadków zmiany te samoistnie nie spowodowały tendencji do działań skutkujących popełnieniem morderstwa jednak w większości przypadków znacznie wzmacniały tendencje i popędy agresywne wyzwolone przez inne detonatory.

Stosunkowo niski - $20 \%$ - był wśród badanych odsetek osób wcześniej karanych sądownie. Było to w dużej, mierze podyktowane specyfiką badanej populacji przebywającej w zakładzie karnym dla odbywających karę po raz pierwszy. Nieco mniejszy bo $-17 \%$ był natomiast odsetek osadzonych przebywających wcześniej w zakładach poprawczych.

U większości badanych osób - 70 \% stwierdzono zespól zależności alkoholowej, który $\mathrm{z}$ reguły ograniczał poczytalność sprawcy w chwili dokonywania przestępczego czynu. U niektórych sprawców - $7 \%$ zdiagnozowano podwójne uzależnienie /od alkoholu i narkotyków/, u kolejnych - 7 \% zdiagnozowano uzależnienie od narkotyków. Osoby u których nie wykryto objawów wspomnianych uzależnień stanowiły $23 \%$ badanej populacji.

Tylko $7 \%$ badanych deklarowało swój udział w więziennej grupie nieformalnej /grypsujących/. Tak niski odsetek członków tej subkultury wiąże się z szerszymi tendencjami spadkowymi w wymiarze ogólnopolskim. Większość badanych sprawców zabójstw - 77 \% miała w chwili dokonywania przestępczego czynu ograniczoną poczytalność. Ograniczenie poczytalności wynikało nie tylko z wcześniejszej intoksykacji alkoholowej lub narkotykowej lecz również z różnego stopnia upośledzenia sprawców. 
W badaniach inteligencji sprawców 50 \% wyników mieściło się w granicach normy, kolejnych $33 \%$ na dolnej granicy normy, zaś $17 \%$ poniżej dolnej granicy normy /upośledzenie umysłowe w stopniu lekkim/. Spośród wszystkich badanych sprawców zabójstw $27 \%$ przejawiało zarówno przed jak i po osadzeniu w jednostce penitencjarnej tendencje autodestrukcyjne /pocięcia, połyki ciał obcych, próby samobójcze/. Osadzeni sprawcy zabójstw są zróżnicowani pod względem wieku. Badani z przedziału 19-30 lat stanowili $35 \%$, w przedziale wiekowym 31-40 lat było ich $15 \%$, w przedziale wiekowym 41 50 lat również $15 \%$, w przedziale wiekowym 51-60 lat także $15 \%$, powyżej 60 lat - $20 \%$.

Charakterystyczne jest, iż największy odsetek stanowią osoby najmłodsze $\mathrm{w}$ wieku przedprodukcyjnym, a bezpośrednio za nimi plasują się osoby najstarsze $\mathrm{w}$ wieku poprodukcyjnym. O ile $\mathrm{w}$ przypadku osób najmłodszych jedną $\mathrm{z}$ głównych przyczyn przestępstwa okazują się być braki w procesie socjalizacji i wyzwolenie niekontrolowanej agresji przy pomocy detonatorów /najczęściej alkohol lub narkotyki/, o tyle w przypadku osób najstarszych główną przyczyną ich zachowania są z reguły nieporozumienia $\mathrm{z}$ osobami najbliższymi.

W sytuacjach konfliktowych i wywołujących stresy $50 \%$ badanych prezentowało zachowania agresywne. Przemoc $w$ rodzinach wstępnych i zstępnych osadzonych stwierdzono na podstawie analizy dokumentacji i wywiadów sporządzonych przez kuratorów sądowych oraz pracowników Ośrodków Pomocy Społecznej. Zjawisko przemocy w rodzinie jako szczególna forma zachowań agresywnych występowała u 20 \% sprawców późniejszych zabójstw. Alkoholizm jako negatywne zjawisko w rodzinach badanych sprawców zabójstw występował w 30 \% przypadków. Możliwości korekcji społecznej /resocjalizacja/ i psychologicznej /terapia/ sprawców zabójstw w polskim systemie penitencjarnym w dużej mierze zależą od długości zasądzonego wyroku oraz od dodatkowych postanowień sądu skazującego. Dotyczy to zwłaszcza możliwości ubiegania się o wcześniejsze warunkowe przedterminowe zwolnienie. W przypadku korekcji społecznej pozytywny wydaje się być wpływ stosunkowo krótkiego pobytu w jednostkach penitencjarnych /do 10 lat/.

W przypadku korekcji psychicznej większe efekty daje długotrwała terapia. W większości jednostek penitencjarnych nie istnieją plany postępowania ze skazanymi na długoletnie wyroki /z reguły są to sprawcy zabójstw/. Tylko w kilkunastu z nich /12\%/ funkcjonują specjalne oddziały dla osadzonych uzależnionych od alkoholu, narkotyków czy osób z zaburzeniami psychicznymi.

W badanej jednostce penitencjarnej nie znajdują potwierdzenia zarzuty sformułowane przez dotyczące braku lub niewłaściwego wykorzystywania wiedzy pochodzącej z badań osobopoznawczych [3].

Wszystkie osoby przybywające do jednostki celem odbycia kary są wszechstronnie diagnozowane, za szczególnym uwzględnieniem kryminogenezy i stopnia demoralizacji. Diagnoza taka, uwzględniająca zarówno czynniki specyficzne jak i niespecyficzne, pomaga personelowi penitencjarnemu we właściwym osadzeniu i rozmieszczeniu skazanych. W dobie przepełnionych ponad rozsądne granice jednostek penitencjarnych rzetelność diagnozy i dokładne rozeznanie osobowości skazanych jest nie tylko formalną lecz i praktyczną koniecznością. Szczególną uwagę personel badanej jednostki przywiązuje właśnie do kryminogenezy sprawców zabójstw, jako jednostek potencjalnie najbardziej niebezpiecznych dla współosadzonych i personelu.

Poza osobami leczącymi się przed popełnieniem przestępstwa w ośrodkach lecznictwa uzależnień, zarówno przed jak i po odbytym wyroku nie zdarzają się przypadki korzystania z usług terapeutycznych przez sprawców zabójstw. Po długotrwałym pobycie w jednostkach penitencjarnych, gdzie zazwyczaj nie biorą udziału w specjalistycznej terapii sprawcy 
zabójstw wychodząc na wolność mogą stanowić „bombę z opóźnionym zapłonem” i przy zaistnieniu podobnych detonatorów, jak w przeszłości, ponownie wkroczyć na drogę przestępczą. Stosunkowo mało informacji udało się uzyskać w badaniach na temat czynnika kryminogenezy jakim jest wtórna dewiacja, wywołana wcześniejszym pobytem w zakładach zamkniętych. Tymczasem, jak podkreśla Szymanowski [4], częste stosowanie w przeszłości izolacyjnych środków karnych było następstwem nieprzystosowania społecznego sprawców prowadząc do utrwalania się kryminogennych mechanizmów w osobowości skazanych.

Badacze rzeczywistości peintencjarnej stają także przed koniecznością zmierzenia się $\mathrm{z}$ negatywną solidarnością społeczną, w ramach której każdy podwładny bądż członek personelu może szantażować drugiego. A uzyskiwane dane pochodzące również z analizy dokumentów nalezy traktować z dużą ostrożnością [6,7].

\section{PODSUMOWANIE}

Ciągle niedocenianym przez administrację penitencjarną czynnikiem kryminogenezy jest wpływ środków masowego przekazu /zwłaszcza obrazów przemocy/. Badacze tego zjawiska [5] zauważają, że nacechowane przemocą metody postępowania są najpopularniejszym środkiem osiągania społecznie pożądanych celów. Chcąc być podobnym do medialnego idola zwłaszcza młodzi ludzie zachowują się agresywnie, nie cofając się nawet przed możliwością pozbawienia kogoś życia, gdyż agresja przynosi powodzenie, a skuteczność $\mathrm{w}$ działaniu to jedna $\mathrm{z}$ najwyższych wartości promowanych we współczesnych mediach.

\section{References}

[1] Pastwa-Wojciechowska B., Wybrane problemy orzecznictwa sadowo psychologicznego w sprawach karnych, Gdańsk, 2000.

[2] Ciosek M., Psychologia sądowa i penitencjarna, Warszawa, 2001, s. 147-148.

[3] Lelental S., Wykonywanie kary pozbawienia wolności w zakładach karnych dla recydywistów, Warszawa, 1992, s. 98-99.

[4] Szymanowski T. Powrót skazanych do społeczeństwa, Warszawa, 1989, s. 103.

[5] Schneider H. J., Zysk z przestępstwa, Warszawa, 1992, s. 100.

[6] Borowski A., International Letters of Social and Humanistic Sciences 1 (2013) 14-18.

[7] Borowski A., International Letters of Social and Humanistic Sciences 3 (2013) 69-74. 